\title{
Freedom, Distribution and Work from Home: Rereading Engels in the Time of the COVID-19-Pandemic
}

\author{
Saayan Chattopadhyay* and Sushmita Pandit** \\ *Baruipur College, Kolkata, India, saayanchattopadhyay@gmail.com \\ **Future Media School, Kolkata, India, sushmitapandit@gmail.com
}

\begin{abstract}
The aim of this paper is to understand the emerging practices of work from home drawing from the works of Friedrich Engels. Situating the rising debate on work from home, particularly in the context of the COVID-19 pandemic, this article revisits some of the texts by Friedrich Engels to understand the issues of distribution, freedom, necessity and work. The idea of work from home becomes especially critical in the context of a developing country like India, with its limited access to digital infrastructure, inadequate work-space at home, and precarious work conditions. However, the digital network and devices play a pivotal role under these conditions and often offer a promise of "new freedom" and flexibility. It is not just the middle-class professionals, but several other dimensions of work and labour are implicated within the idea of work from home under sudden economic and social disruption. The new organisation of production, assisted by capitalism, forges new relations of production, and new predicaments and Engels's thoughts on freedom, work and the condition of the working class become increasingly relevant to understand these shifts, particularly in neoliberal, developing country like India under nationwide lockdown.
\end{abstract}

Keywords: pandemic, work from home, Friedrich Engels, Karl Marx, freedom, migration, distribution, COVID-19, coronavirus

\section{Introduction}

The novel coronavirus or COVID-19 pandemic has created an unprecedented situation in almost every sphere. From the initial days of the pandemic, both developed and developing nations appeared to be particularly vulnerable and often inadequate in the fight against the virus. The impact has been considerably more complex and multifaceted in developing countries like India, Bangladesh, and Africa. The virus, explain Jean-Luc Nancy and Jean-François Bouthors (2020), by its novelty, its speed of transmission, the surprises it holds in store for us in terms of its modes of action on the organism, and above all, because many of the people it infects are asymptomatic carriers - places us in a situation of extreme uncertainty. It also demands a certain degree of interdependence that no country, however large and powerful, can save itself by its own efforts alone.

The virus seems to have an inherent class identity, as it was initially spread by individuals who have travelled internationally. Moreover, the first confirmed cases are largely in urban areas, among the affluent classes, and slowly spreading towards the rural territories and poor people. A news report mentions, "When it arrived in the unforgiving industrial towns of central Mexico, the sand-swept sprawl of northern Nigeria and the mazes of metal shanties in India's commercial capital, Mumbai, COVID-19 went by 
another name. People called it a 'rich man's disease"' (Bengali et al. 2020). Moreover, as Fuchs (2020) explains, in the coronavirus crisis, "the home has become the supra-locale of everyday life". The social spaces and locales of work, education, the public sphere, the private sphere all converge in in the locale of the home. Consequently, the allocation of time and the organization of everyday life has become exceedingly difficult for the overburdened individual juggling "multiple social roles at the same time in one locale" (379). Therefore, the pandemic problematises a number of issues under capitalism and the time seems ripe to look at how the deep-rooted problems of labour, value, class divisions, relations of production change with the mutations of capitalism. This article, however, limits its scope within the discussion of work from home during the pandemic and revisits some of the texts written by Friedrich Engels to understand how the notions of work, home, freedom and necessity reconfigure within a larger framework of understanding power and resistance in the Marxian tradition.

The analysis that follows starts from the assumption that "digital communication technologies have not transformed our society in a way that changes its underlying capitalist nature. Hence, we can and should analyze contemporary capitalism with established analytical and theoretical categories. The other is that digital communication technologies are implicated in a radical transformation in capitalism, one which requires us to re-evaluate, re-formulate, and update our Marxist categories to account for these transmutations" (Fuchs and Fisher 2020, 3).

In the first section, the article focuses on the emerging practices of work from home and the salaried middleclass or upwardly middleclass. Although work from home seems to be a beneficial policy for working professionals, there are some tenacious and entrenched questions that need to be addressed to critically understand what the conditions of the working class look like in the pandemic situation. Drawing from Engels's conceptualisation of distribution and the material conditions of existence, we argue that the primary problematic of work from home is the crisis of uneven distribution. The second section deals with the triumphant rhetoric of work from home that foregrounds the ideas of greater freedom and flexibility. Re-reading sections from Engels's Anti-Dühring (1878), the article questions freedom from what and freedom for whom. The paper shows that the employees working from home for information technology services or software firms, like any other workers, are not free, but being controlled "by the very object it should itself control" (Engels 1878, 106). Hence, the freedom that the software or IT professionals working from home enjoy is evidently negative freedom. The third section addresses the crisis of migrant workers and underlines the problem of the opposition between work and home for these labourers. We identify parallells with the antithesis between town and country that Engels was talking about in his series of articles on The Housing Question in 1872.

\section{Work from Home and the Precarious Salaried Middleclass}

The idea of work from home is largely discussed around the specific community of salaried middleclass or upwardly middleclass ${ }^{1}$. The prolonged lockdown and stay at home

1 Since these employees do not produce commodities but are largely engaged in managing, servicing and distributing on behalf of the owners of the businesses, they can be termed petty- 
mandate initiated varied types of work from home practices that continued for months. One of the first large companies to declare the provision of work from home until the middle of 2021 for its employees was Google. The parent company, Alphabet Inc. did not only extend the work from home (WFH) provision for its US employees but also extended the offer for its employees working in Google India, Brazil and UK (Copeland and Grant 2020). Twitter on the other hand, announced that their employees might consider working from home "forever". Similarly, Facebook also adopted WFH and claimed that they are planning to allow half of all employees to work from home by 2030 (Sandler 2020).

In India, which is considered to be one of the most sought-after countries for setting up an offshore development centre because of its cost-effectiveness and it holds around sixty-five percent of the outsourced IT jobs, most of the large information technology companies declared work from home policies with the spread of the pandemic. From April 2020 onwards, most of the information technology companies based in India started announcing their work from home policies (PTI 2020). Tata Consultancy Services (TCS) was one of the first Indian companies to announce work from home for its employees and claimed that within the next five years, seventy-five percent of its global employees would be permanently working from home (Khetrapal 2020). Subsequently, Infosys an Indian multinational corporation that offers information technology and outsourcing services announced that more than thirty percent of its employees would be permanently working from home even in post-COVID situation (ET 2020). As per newspaper reports, the top five IT companies in India, TCS, Infosys, HCL Tech, Wipro and Tech Mahindra together have over 1.1 million employees on their payrolls for the quarter ended June and a ninetyfive percent average would mean more than one million employees working from home (Srikanth 2020).

The IT sector is also witnessing some significant structural changes as well in response to the pandemic induced work from home. According to Hyderabad Software Enterprises Association (HYSEA) a number of start-ups and small and medium enterprises are already cancelling their lease contracts of office premises, as they are thinking about alternative modes of operations after the introduction of almost mandatory work from home during the COVID-19 pandemic. Since for most of the IT companies, thirty percent of the cost is establishment or office space, this new arrangement is supposed to be beneficial both ways (Maitreyi 2020). Similarly, the young IT professionals from other states who were staying in the city in shared accommodation are now terminating their rental contracts as they are continuing work from home from their home state (Aravind 2020).

While work from home sounds like a favourable option for a number of working professionals, there are some pressing and deep-rooted issues that need to be underlined to better understand the condition foregrounded by the pandemic situation. Fuchs (2014, chapter 8) in his case study of digital labour in India shows that the strategies of virtual migration and body shopping organise space in a racist manner for exploiting Indian labour in such a way that "it is highly exploited, individualized, dispersed, isolated, precarious, non-unionized and for cheapening labour-power so that the wage costs are low and profits can be maximized" (2014, 205). Moreover, since most of the IT companies are engaged in outsourced projects, the value produced by these companies

bourgeois. They may not always relate to the working-class consciousness since they are supposed to have some degree of control over the bourgeois apparatus. 
are ultimately "appropriated and owned by Western capital, which accumulates capital by selling software based on the dispossession of the value created by Indian software engineers in such a way that high exploitation rates are given" (211). While a number of studies have focused on this macro level exploitative structure of Indian software companies, let us now focus on the specific case of work from home.

\section{Distribution and the Material Conditions of Work from Home}

One of the major problems of working from home, especially in a developing country like India is the unequal access or distribution of equipment and services necessary for conducting work from home. It is important to mention that unequal access to or distribution of equipment and services does not only entail personal computers, webcams and smartphones but also such basic infrastructures such as uninterrupted electricity, access to clean water, separate room or space for a work-set up, availability of broadband connection" ${ }^{2}$. Friedrich Engels reminds us that "[...] with the differences in distribution, class differences emerge" and the division between the privileged and the dispossessed, the exploiters and the exploited, the rulers and the ruled are maintained so that the conditions of domination of the ruling class against the subjected class are perpetuated (Engels 1878, 136-137). Distribution, Engels emphasises, however, is not merely a passive result of production and exchange; it in its turn reacts upon both of these (Engels $1878,137)$. The primary problematic of work from home, we would argue, is the problem of unequal distribution, even among the salaried, urban middle class.

While at the beginning, there was an acute shortage of work from home equipment, soon rising consumption of such accessories, including furniture witnessed an exponential increase, mainly in the urban areas (Mishra 2020) ${ }^{3}$. However, it is pertinent to ask, who are able to buy these products and services? As pointed out by many reports, there are wide differences in the salary and other financial benefits among the salaried employees in India (GOI 2019). Excluding a few multinational companies, none of the organisations provided a separate laptop or other accessories and did not offer separate allowances for buying the appropriate furniture or for installing Internet routers. The claims for additional allowance to make up for the added electricity and Internet bills are often disused by the corporations, even in developed countries (Collinson 2020).

The sphere of the home itself posits difficulties for the software or IT worker. Following work from home policies, to a certain extent, the use-value of the "home" is enhanced as it becomes the site of production since use-value is generated only through use or consumption. However, a significant number of middleclass employees do not have a separate workspace. In fact, reports published during the pandemic point out that about forty-one percent of households in India have just one room or don't have a separate

${ }^{2}$ Distribution to a certain extent appears to be almost as a pre-economic component that precedes production. An individuals' position in the society is determined by distribution.

3 During the pandemic period, Amazon India's sale was marked as the single biggest two-day promotional event this year. Although initially online sales were down but soon sales of online retailers have exceeded pre-COVID-19 levels in terms of volume, mainly due to purchase of grocery and essential items. Personal computing, large appliances, and smartphones were the top-selling categories. Even at the highest number of infected populations, in US Amazon recorded biggest profit ever. The company said revenue increased forty percent from last year. Amazon's shares have increased by more than sixty percent in 2020. 
living room and often about five people share such accommodations (Jadhav 2020). About thirty-two percent of households, according to reports, have two room household, however, only forty-seven percent of households have access to water within the building premises and forty-two percent do not have the provision to take a shower inside their house (Jadhav 2020). These facts came into light not in the context of work from home, rather in reference to the Union Ministry of Health and Family Welfare, Government of India's guideline on home quarantine, which stated that one should "[s]tay in a wellventilated single-room preferably with an attached/separate toilet" (GOI 2020) ${ }^{4}$. Therefore, it becomes evident that when a substantial percentage of even the urban population in India is not in a position to follow the guideline on home quarantine, then how can we expect to have a suitable work from home facility for the majority of IT employees. Hence, this is a problem of distribution, not only distribution of goods and services, but also about the distribution of wealth, property, basic amenities, and household services ${ }^{5}$.

Distribution, explains Marx $(1857 / 1858,96)$ in Grundrisse, in general, means the distribution of products; it is thus "further removed from and made quasi-independent of production". However, he is quick to point out, before distribution becomes the distribution of products, it is firstly, the distribution of the means of production, and second, the distribution of particular individuals among specific types of productions, in other words, "the subsuming of the individuals under definite relations of production" (Marx 1857/1858, 96). Since production must proceed from a specific distribution of the means of production, distribution is to this extent antecedent to and a prerequisite of production. It is evident that those "distribution which is initially a factor of production" further invests in increased consumption, particularly in the context of work from home that in turn, provides impetus to the capitalist structure of production.

4 The idea of home quarantine was exceedingly difficult since a large number of people do not have essential amenities in the premise. Even in urban areas, thirty-six percent household do not have clean water source within 100 meters radius and in rural territory it increases to 500 meters.

${ }^{5}$ While all these elements seem economic, it is useful to remember what Engels wrote on the importance of economic element in the historical struggles in his letter to Joseph Bloch in 1895: "According to the materialist view of history, the determining factor in history is, in the final analysis, the production and reproduction of actual life. More than that was never maintained either by Marx or my- self. Now if someone distorts this by declaring the economic moment to be the only determining factor, he changes that proposition into a mean- ingless, abstract, ridiculous piece of jargon. The economic situation is the basis, but the various factors of the superstructure - political forms of the class struggle and its consequences, namely constitutions set up by the ruling class after a victorious battle, etc., forms of law and, the reflections of all these real struggles in the minds of the participants, i. e. political, philosophical and legal theories, religious views and the expansion of the same into dogmatic systems - all these factors also have a bearing on the course of the historical struggles of which, in many cases, they largely determine the form. It is in the interaction of all these factors and amidst an unending multitude of fortuities (i. e. of things and events whose intrinsic interconnections are so remote or so incapable of proof that we can regard them as non-existent and ignore them) that the economic trend ultimately asserts itself as something inevitable. Otherwise the application of the theory to any particular period of history would, after all, be easier than solving a simple equation of the first degree" (Engels 1890, 34-35). 


\section{Negative Freedom and The Mechanisms of Control}

Let us now come to the idea of freedom. The celebratory rhetoric of work from home often employs the ideas of greater freedom and flexibility. But it might be useful to question freedom from what and freedom for whom? Even in the context of the developed nationstates, a passing glance at the journalistic articles points to the inevitable struggles associated with working from home. One such article mentions,

An executive at JPMorgan Chase \& Co. gets unapologetic messages from colleagues on nights and weekends, including a notably demanding one on Easter Sunday. A web designer whose bedroom doubles as an office has to set the alarm to remind himself to eat during his non-stop workday. At Intel Corp., a vice president with four kids logs 13-hour days while attempting to juggle her parenting duties and her job[...] whatever boundaries remained between work and life have almost entirely disappeared (Davis and Green 2020).

A global survey conducted by one of the personal virtual private network service providers indicated that during the work from home period employees are working longer hours than usual. While the US increased their average workday by almost forty percent, Canada, France, Spain and the UK witnessed two hours increase each day (Meakin 2020) ${ }^{6}$.

In the context of developing nations, like India, where labour rules are historically lenient and often goes unreported and unmonitored, the picture is even grimmer.

At a top strategy consulting firm, a partner says he logs in for calls at 8am, and that continues till $10 \mathrm{pm}$ and sometimes beyond, as people schedule meetings irrespective of time zones and holidays. Another senior executive working out of a guest house in Bengaluru routinely ends up missing lunch during his non-stop workdays. Employees, some of whom are working till the wee hours of the morning, aren't getting me-time or family time; there are complaints of headaches and body aches, which again is leading to anxiety and depression because, given the current job situation, they feel they have no choice [...] Most are working much more despite salary deductions (Philip and Basu 2020) ${ }^{7}$.

6 The human resource (HR) departments of the corporations are also divided on this issue. While some of the think that employers need to draw a line. "They can't intrude into employee privacy and personal time", others believe that it is the employees' responsibility to be self-disciplined and create boundaries for working hours (Lijee and Basu 2020).

7 A few of the recognized entrepreneurs voiced their opinion to increase the work hours to compensate for the economic loss during COVID-19. For instance, Narayana Murthy, cofounder of Infosys in India said Indians must work for sixty hours a week for the coming twothree years to compensate for the coronavirus lockdown. Similarly, Jack Ma co-founder of Alibaba Group claimed that Chinese workers should work for twelve hours daily. However, none of them addressed the issue of improving working condition, over-time compensation and the complex impact of working hours increase on economy. 
The precarity of such work conditions was already existing and the COVID-19 pandemic has only augmented its impact. The conditions produced by the COVID-19 pandemic have foregrounded some of the basic questions posed by Engels and Marx.

While work from home often promises freedom for the individual, this freedom consists of a "dreamt-of independence" from the idea of being present in the office. As Engels explains in Anti-Dühring,

Freedom does not consist in any dreamt-of independence from natural laws, but in the knowledge of these laws, and in the possibility this gives of systematically making them work towards definite ends. This holds good in relation both to the laws of external nature and to those which govern the bodily and mental existence of men themselves - two classes of laws which we can separate from each other at most only in thought but not in reality (Engels 1878, 105).

Thus, the majority of the individuals being uncertain and more importantly ignorant of the oppressive structure seem to make an arbitrary choice among many different and conflicting possible decisions. This shows that "it [the individual] is not free, that it is controlled by the very object it should itself control" (Engels 1878, 106).

It is important to reiterate here that "freedom, therefore, consists in the control over ourselves and over external nature, a control founded on knowledge of natural necessity; it is therefore necessarily a product of historical development" (Engels 1878, 106). With this insight from Engels, we may move into the more established Marxist categories and state that the freedom that the software or IT professionals working from home enjoys is negative freedom.

Marx and Engels state that the history of bourgeois society shows an inclination towards offering abundant negative freedom. For instance, wage-labour, free trade lifts the various constraints on freedom of action and mark the characteristic bourgeois freedoms. However, both wage-labour and free trade expands the scope of profit for the capitalist and hence, "this negative bourgeois freedom is a kind of freedom which is real only for those who own the means of production" (MIA 2018). In contrast, positive freedom is gained historically through working-class struggle. Freedom gained through prolonged movements and protests, such as limiting labour time, public health systems, free compulsory education and right to unionise that in fact may pose constraints on the scope of profit for the capitalists. In that sense, bourgeois democracy, by its own structure does not allow, at least voluntarily, any positive freedom that the wage-workers may benefit from.

Then how do we understand this "new freedom"? Distinguishing disciplinary societies in the eighteenth and nineteenth centuries from the societies of control, Gilles Deleuze (1992) mentions in his short yet polemical essay that in disciplinary societies, the "individual never ceases passing from one closed environment to another"; individuals are trained or punished at various times in their by systems such as schools, the factory, the prison, or the family (Deleuze 1992, 3). On the contrary, societies of control - which emerged after World War II, are continuous in form and mark the present conditions of life. If the dominant model in disciplinary society was the factory, then in control societies, the dominant model is that of the "market". "Enclosures are molds, distinct castings, but controls are a modulation, like a self-deforming cast that will continuously change from one moment to the other, or like a sieve whose mesh will transmute from point to point" 
(Deleuze 1992, 5). Thus, the IT employee, who is working from home may find a "new freedom, but they could participate as well in mechanisms of control that are equal to the harshest of confinements" (Deleuze 1992, 4). While he is "free" to work from home, he is bound by a number of digital communication technologies that not only eat into his leisure time but also encroach his privacy and demands longer hours of engagement.

\section{The Antithesis Between Home and Work: Migration and The Social Question}

The idea of a safe home is not only confined to middleclass, salaried individuals. During the pandemic, a significant number of people from different occupations required the shelter of home. Here, it may be interesting to point out the massive migrant workers crisis in India that became the point of national debate and received much international attention.

In India, large and small companies, businesses and industries are significantly dependent on migrant workers. Unlike the developed nations, where migrant workers travel across national borders, in India, it is mainly internal migration, where labourers migrate from one state to another within the nation for work. These migrant workers are engaged in a number of different jobs, from construction work of new office buildings, cleaning and maintenance, to food supply, housekeeping and security. While workers engaged in software and IT companies usually means the white-collar worker, a large number of migrant workers are also part of digital capitalism, albeit almost invisibly. More visible counterparts are engaged in factories and particular production and manufacturing facilities.

On 24 March, 2020, the Government of India under Prime Minister Narendra Modi ordered a nationwide lockdown for 21 days, with four hours' notice. The declaration mandated a stay at home order for India's population of 1.3 billion: This was "the most severe step taken anywhere in the war against the coronavirus" (Gettleman and Schultz 2020). Several arrests across the states were made for violating norms of lockdown. The nationwide lockdown was extended thrice and continued till the end of May with conditional relaxations. ${ }^{8}$

During the nationwide lockdown, most of the migrant workers engaged in informal contract work were out of work since the offices, cafeterias, restaurants, and factories were closed for an indefinite period. A substantial number were evicted from their rented homes in which the labourers stayed in the city, as they were unable to pay the rent. With the rising COVID 19 cases, a number of state governments drove anxious, unemployed migrants into shelter homes. The unpreparedness of the state to tackle the sudden problem of large-scale homelessness because of the lack of work came to the forefront. First of all, there were very few shelters in response to more than 40 to 60 million stranded migrant workers. Second, most of the shelters or "safe homes" for the migrant workers are, in fact, "porta cabins: rectangular, non-sturdy, cargo-container-like structures. Most of them are designed to accommodate around 50 people to sleep comfortably. They are

${ }^{8}$ Since June 2020 onwards The MHA issued new guidelines stating that the phases of reopening would be targeted towards improving the economy. Lockdown restrictions were limited within the containment zones, and some other activities were gradually permitted in a phased manner. 
on average $800 \mathrm{sq} \mathrm{ft}$, which means each person gets about $15 \mathrm{sq} \mathrm{ft}$, about the area of a train berth" (Imaan 2020) ${ }^{9}$.

This dreadful combination of pandemic, unemployment, homelessness and hunger forced the workers to embark on homeward journeys of thousands of miles as all modes of transport were closed down due to lockdown. India had not witnessed anything like this mass migration across the plains of the country without food or a night's place of stay for sleep since the days of the Partition of the subcontinent (Samaddar 2020, II). While there is a lack of data but according to some estimates, more than three hundred migrant workers died on their way home. "Some died on the way due to illness, while others died in road accidents. Some died of exhaustion after walking home in the scorching heat" (Scroll 2020).

This incident foregrounds the idea of home or a "safe home" once again, particularly in relation to work in the context of COVID-19 pandemic in developing nations. It may be useful here to revisit the series of three articles by Engels originally published in Leipziger Volksstaat. These articles address an important debate articulated in Germany's democratic press, centred around the problem of housing shortage for the workers in major industrial centres. Now it is important to understand how the "housing question" is connected to "the social question". Engels posits the "kernel of the problem" as the antithesis of town and country. "The housing question can be solved only when society has been sufficiently transformed for a start to be made towards abolishing the antithesis between town and country, which has been brought to its extreme point by present-day capitalist society" (Engels 1872, 347). He asserts that the housing question cannot be solved without the abolition of the big cities, which is a corollary to the abolition of the capitalist mode of production. While he is aware of the utopian tone of such a statement but he states that it is "no more and no less utopian than the abolition of the antithesis between capitalists and wage workers" (Engels 1872, 384).

More than 2.5 million migrant workers who have come to Mumbai from other states like Uttar Pradesh, Bihar, Madhya Pradesh, West Bengal, Jharkhand and even far off states like Manipur, Assam and Mizoram craved to return home on Shramik Special trains (Workers' Special trains). The crisis brought forward the otherwise-invisible migrant workers' crisis and underlined the unavailability of the shelter for the migrant workers, the grim condition of the houses where they live in cramped up conditions and the unpreparedness of the state. However, as Engels explains in response to the housing question and the idea of "supplying each worker with a little house for his own possession":

Let us assume that in a given industrial area it has become the rule that each worker owns his own little house. In this case the working class of that area lives rent free; expenses for rent no longer enter into the value of its labor power. Every reduction in the cost of production of labor power, that is to say, every permanent price reduction in the worker's necessities of life is equivalent 'on the basis of the iron laws of political economy' to a reduction in the value of labor power and will therefore finally result in a corresponding fall in wages. Wages would fall on an

${ }^{9}$ One of the major missteps was to conflate the homeless and the migrant workers. As news reports mentioned many of the stranded migrants had never lived in homeless shelters, simply because they are not homeless. 
average corresponding to the average sum saved on rent, that is, the worker would pay rent for his own house, but not, as formerly, in money to the house owner, but in unpaid labor to the factory owner for whom he works. In this way, the savings of the worker invested in his little house would certainly become capital to some extent, but not capital for him, but for the capitalist employing him (Engels 1872, 345).

In today's context, Engels's quote underlines in what way the hue and cry about the shortage of labour shelter in Mumbai offsets the more pressing concern of why, for example, a worker from Mizoram needs to travel thousands of miles to Mumbai for finding work. And the same is also applicable for the software and IT professional working in Bangalore, Gurgaon or Noida, who has to rent a place thousand miles away from home. Hence, what Engels was trying to emphasise is that reforms policies cannot be the solution to problems that require revolutionary class politics in order to be solved. The widening gap between small towns and urban areas in India has witnessed a rising number of migrations from rural areas to the city. This reminds us the antithesis between town and country that Engels was talking about in 1872. "The abolition of the antithesis between town and country", Engels wrote, "from day to day it is becoming more and more a practical demand of both industrial and agricultural production" (Engels 1872, 384).

This antithesis becomes even more apparent as the migrant laborers, upon returning "home", are neither finding work nor adequate financial support from the government. As a substantial number of reports and articles reveal, a large number of migrants who have gone back to their home states are experiencing an acute shortage of work. For example, groups like Ghar Bachao, Ghar Banao Andolan (Save Home, Construct Home Movement) continuously received desperate calls from migrant workers, who are finding it hard to get any kind of employment in their home town and now desperately wants their job back in Mumbai or Delhi. "They have mortgaged their family's jewelry" a news report mentions, "and if they fail to find work, whatever little land they have, will be sold. Those who have returned are unable to even get access to universal PDS [Indian food security system], as their ration cards are back home" (Modak 2020).

While the government has increased funding for social security measures to ₹1 trillion, the highest ever since its inception in 2006, such measures cannot be a long-term solution, since with the increasing number of rural households applying for such schemes to make ends meet, "a household is unlikely to get more than fifty days of work on average, despite the higher funding" (Bera 2020).

Coming back to the antithesis that Engels pointed out: the problem, crudely put, is that where there is "home" there is no work and where there is work there is no "home". Interestingly, the agricultural sector, which is supposed to provide "work" in the rural areas has witnessed a steady "feminisation" over the years (Jiggins 1998). According to the Economic Survey 2017-18, with the increase in migration of men from rural to urban areas, the number of women in multiple roles such as cultivators, entrepreneurs and labourers is increasing, resulting in the "feminisation" of the agricultural sector (GOI 2018). As per the survey, women increasingly dominate all levels of the agricultural value chain, including pre-harvest, production, post-harvest processing, packaging, and 
marketing (Vasudeva 2018) ${ }^{10}$. Men who migrated to urban areas now consider agricultural work as "women's work" and find it difficult to adapt to the structural changes, even though the Indian economy remains predominantly an agricultural economy ${ }^{11}$.

\section{Conclusion}

Capitalist rule cannot allow itself the pleasure of creating epidemic diseases among the working class with impunity; the consequences fall back on it and the angel of death rages in its ranks as ruthlessly as in the ranks of the workers.

Engels $(1872,337)$ wrote these lines 148 years ago and now it becomes particularly relevant in understanding such categories of work, home and freedom and distribution in the context of the COVID-19 pandemic. As the novel Corona virus continues to make us confront unprecedented challenges, it is already reconfiguring our relationships to the nation-state, corporations, government, even to each other. Engels reminds us that the established structures of oppression and subjugation continue to exist, if not in a more aggressive manner, in most of the sectors during the pandemic. What the COVID-19 crisis has taught in the light of Friedrich Engels's thought is that it is necessary to consider the pandemic as a social question and not only as reforms related to health, economy and governance. The invisibility of certain kinds of labour and the everyday struggles associated with it has now come to the forefront. The pandemic also offered an entry point into the class politics of urban salaried middleclass, often employed within the networks of digital capitalism, and Engels's distinctively working-class outlook and political theory can be a valuable lens to explore it further.

\section{References}

Aravind, Indulekha. 2020. COVID impact: Professionals who can work from home are ditching the uncongenial cities. The Economic Times, July 13. Accessed August 25, 2020. https://economictimes.indiatimes.com/news/company/corporate-trends/safe-houseprofessionals-who-can-work-from-home-are-ditching-the-uncongenialcities/articleshow/76912728.cms

Bengali, Shashank, Kate Linthicum and Victoria Kim. 2020. How coronavirus - a 'rich man's disease' - infected the poor. Los Angeles Times, May 8. Accessed September 20, 2020. https://www.latimes.com/world-nation/story/2020-05-08/how-the-coronavirus-began-as-adisease-of-the-rich

10 Notably, as per Census 2011, out of total female main workers, fifty-five percent were agricultural labourers and twenty-four percent cultivators. However, little more than twelve percent of the operational holdings were owned by women, which revealed the gender inequality in ownership of landholdings in agriculture.

${ }^{11}$ However, we are not suggesting that migrant workers must revert back to being agricultural labourers. Since, Engels would not agree on maintaining the peasant as such. "Only as uniform a distribution as possible of the population over the whole country, only an integral connection between industrial and agricultural production together with the thereby necessary extension of the means of communication - presupposing the abolition of the capitalist mode of production - would be able to save the rural population from the isolation and stupor in which it has vegetated almost unchanged for thousands of years" (Engels 1872, 384). 
Bera, Sayantan. 2020. Citing lack of jobs back home, migrants eye a return to cities. Mint, 9 June. Accessed September 11, 2020. https://www.livemint.com/news/india/citing-lack-ofjobs-back-home-migrants-eye-a-return-to-cities-11591645708141.html

Collinson, Patrick. 2020. Should your employer pay your bills if you work from home? The Guardian, January 17. Accessed August 21, 2020.

https://www.theguardian.com/money/2020/jan/17/should-employer-pay-broadband-workinghome-cqc

Copeland, Rob and Peter Grant. 2020. Google to Keep Employees Home Until Summer 2021 Amid Coronavirus Pandemic. Wall Street Journal. July 27. Accessed August 4, 2020. https://www.wsj.com/articles/google-to-keep-employees-home-until-summer-2021-amidcoronavirus-pandemic-11595854201

Davis, Michelle F. and Jeff Green. 2020. Three Hours Longer, the Pandemic Workday Has Obliterated Work-Life Balance. Bloomberg, April 23. Accessed September 10, 2020. https://www.bloomberg.com/news/articles/2020-04-23/working-from-home-in-COVID-erameans-three-more-hours-on-the-job

Deleuze, Gilles. 1992. Postscript on the Societies of Control. October 59 (1992): 3-7. http://www.jstor.org/stable/778828

Engels, Friedrich. 1890. Engels to Joeph Bloch, 21/22 September. In Marx \& Engels Collected Works (MECW) Volume 49, 33-37. London: Lawrence \& Wishart.

Engels, Friedrich. 1878. Anti-Dühring. Herr Eugen Dühring's Revolution in Science. In Marx \& Engels Collected Works (MECW) Volume 25, 5-309. London: Lawrence \& Wishart.

Engels, Friedrich. 1872. The Housing Question. In Marx \& Engels Collected Works (MECW) Volume 23, 317-391. London: Lawrence \& Wishart.

ET. 2020. Keep Calm and Work from Home! Tech \& IT Giants That Are on WFH Mode till July 2021. The Economic Times, 25 August. Accessed September 17, 2020.

https://economictimes.indiatimes.com/magazines/panache/keep-calm-and-work-from-hometech-it-giants-that-are-on-wfh-mode-till-july-2021/embracing-the-newnormal/slideshow/77740411.cms

Fuchs, Christian. 2020. Everyday Life and Everyday Communication in Coronavirus Capitalism. tripleC: Communication, Capitalism and Critique 18 (1): 375-399.

https://doi.org/10.31269/triplec.v18i1.1167

Fuchs, Christian. 2014. Digital Labor and Karl Marx. New York: Routledge.

Fuchs, Christian and Eran Fisher. 2020. Reconsidering Value and Labour in the Digital Age. New York: Palgrave Macmillan.

Gettleman, Jeffrey and Kai Schultz. 2020. Modi Orders 3-Week Total Lockdown for All 1.3 Billion Indians. The New York Times, 24 March. Accessed September 9, 2020. https://www.nytimes.com/2020/03/24/world/asia/india-coronavirus-lockdown.html

GOI [Government of India]. 2020. Guidelines for home quarantine. Ministry of Health \& Family Welfare. Accessed September 9, 2020.

https://www.mohfw.gov.in/pdf/Guidelinesforhomequarantine.pdf

GOI [Government of India]. 2019. Periodic Labour Force Survey (PLFS) 2017-2018. Ministry of Statistics and Programme Implementation. Accessed October 15, 2020. http://www.mospi.gov.in/sites/default/files/publication reports/Annual\%20Report\%2C\%20PL FS\%202017-18 31052019.pdf

GOI [Government of India]. 2018. Economic Survey 2017-2018. Ministry of Finance. Accessed September 9, 2020. http://mofapp.nic.in:8080/economicsurvey/

Imaan, Anhad. 2020. India's Migrant Crisis Pointed to Another Problem - Its lack of Shelter Homes. Scroll, 31 July. Accessed September 11, 2020. https://scroll.in/article/968374/indiasmigrant-crisis-pointed-to-another-problem-its-lack-of-shelter-homes 
Jadhav, Radheshyam. 2020. COVID-19: On Why Home Quarantine is Impossible for the Majority of Indians. The Hindu Business Line, 5 August. Accessed September 12, 2020. https://www.thehindubusinessline.com/news/COVID-19-on-why-home-quarantine-isimpossible-for-the-majority-of-indians/article32275067.ece

Jiggins, Janice. 1998. The Feminization of Agriculture. The Brown Journal of World Affairs 5 (2): 251-62. http://www.jstor.org/stable/24590325

Khetrapal, Sonal. 2020. Post-COVID, 75\% of 4.5 Lakh TCS Employees to Permanently Work From Home by '25; from 20\%. Business Today. 30 April 2020. Accessed August 13. https://www.businesstoday.in/current/corporate/post-coronavirus-75-percent-of-3-5-lakh-tcsemployees-permanently-work-from-home-up-from-20-percent/story/401981.html

Maitreyi, M.L. Melly. 2020. With WFH, New Dynamics at Play in IT ector. The Hindu, 14 June. Accessed August 25, 2020. https://www.thehindu.com/news/cities/Hyderabad/with-wfh-newdynamics-at-play-in-it-sector/article31828380.ece

Marx, Karl. 1867. Capital. Volume I. London: Penguin.

Marx, Karl. 1857/1858. Grundrisse: Foundations of the Critique of Political Economy. London: Penguin.

Meakin, Lucy. 2020. Working From Home Means Working Longer Hours for Many. Bloomberg, 23 March. Accessed September 9, 2020. https://www.bloomberg.com/news/articles/2020-0323/working-from-home-means-working-longer-hours-for-many-chart

MIA [Marxists Internet Archive]. 2018. Freedom. Marxists Internet Archive Encyclopedia. Accessed September 9, 2020. https://www.marxists.org/glossary/terms/f/r.htm

Mishra, Smriti. 2020. How \#wfh Has Benefitted Offline and Online Furniture Firms. Financial Express, 8 September. Accessed September 23, 2020.

https://www.financialexpress.com/brandwagon/how-wfh-has-benefitted-offline-and-onlinefurniture-firms/2077548/

Modak, Sadaf. 2020. Maharashtra: Migrant Workers Return to Scarce Jobs, Low Salaries. The Indian Express, 13 August. Accessed September 11, 2020.

https://indianexpress.com/article/cities/mumbai/migrant-workers-return-to-scarce-jobs-lowsalaries-6552377/

Nancy, Jean-Luc and Jean-François Bouthors. 2020. Only Democracy Can Allow Us to Accept the Lack of Control Over Our History. Verso Blog. Accessed September 15, 2020.

https://www.versobooks.com/blogs/4772-only-democracy-can-allow-us-to-accept-the-lack-ofcontrol-over-our-history

Philip, Lijee and Sreeradha D Basu. 2020. Excessive Weight Gain, Longer Work Hours, Intrusion Into Weekends \& Holidays: Remote Working Comes With Side-Effects. The Economic Times, Jun 24. Accessed September 11, 2020.

https://economictimes.indiatimes.com/magazines/panache/excessive-weight-gain-longerwork-hours-intrusion-into-weekends-holidays-remote-working-comes-with-sideeffects/articleshow/76543675.cms

PTI. 2020. Government Extends Work From Home Norms for IT, ITes Companies till December 31. The Hindu, 22 July. Accessed August 13, 2020. https://www.thehindu.com/business/Industry/government-extends-work-from-home-normsfor-it-ites-companies-till-december-31/article32155206.ece

Samaddar, Ranabir. 2020. Borders of an Epidemic: COVID-19 and Migrant Workers. Kolkata: Mahanirban Calcutta Research Group.

Sandler, Rachel. 2020. Half of Facebook's Employees May Permanently Work from Home By 2030, Zuckerberg Says. Forbes, 21 May. Accessed August 10, 2020. https://www.forbes.com/sites/rachelsandler/2020/05/21/half-of-facebooks-employees-maypermanently-work-from-home-by-2030-zuckerberg-says/ 
Scroll. 2020. Migrant Crisis: No Data on Deaths of Workers During Lockdown, 10.4 Crore Returned Home, Says Centre. Scroll, 31 July. Accessed September 10, 2020. https://scroll.in/latest/973074/migrant-crisis-no-data-on-deaths-of-workers-during-lockdown10-4-crore-returned-home-says-centre

Srikanth, Chandra R. 2020. More Than 10 Lakh Employees at TCS, Infosys, HCL, Wipro, Tech Mahindra Continue to Work From Home. Times Now, 28 July. Accessed August 25, 2020. https://www.timesnownews.com/business-economy/industry/article/more-than-10-lakhemployees-at-tcs-infosys-hcl-wipro-tech-mahindra-continue-to-work-from-home/628184

Vasudeva, Vikas. 2018. Farm sector sees 'feminisation', says Survey. The Hindu, 12 February. Accessed September 11, 2020. https://www.thehindu.com/business/farm-sector-seesfeminisation/article22564340.ece

\section{About the Authors}

Saayan Chattopadhyay

Saayan Chattopadhyay is an Assistant Professor and Head of the Department of Journalism and Mass Communication at Baruipur College, affiliated to the University of Calcutta, India. After a stint as a journalist, he is currently engaged in research involving digital media and society in India. He has published articles in Journalism Practice, Media Asia, South Asia Research, Studies in South Asian Film and Media, Journal of Boyhood Studies. He has also contributed chapters in books on media, gender and technology published from Oxford University Press, Palgrave Macmillan, Springer, Routledge, Lexington Books, Sussex Academic Press, among others. His research interests include media philosophy, cultures of mobility, South Asian masculinities, and techno-culture in developing countries.

\section{Sushmita Pandit}

Sushmita Pandit is an Assistant Professor of Media Studies at Future Media School, Maulana Abul Kalam Azad University of Technology, India. She also works as a radio presenter at All India Radio, Kolkata. She has published her works in journals such as Journalism Practice, Media Asia, Journal of Digital Media and Policy and Global Media Journal, among others. Her research interest includes digital humanities, television studies and media policy. 